\title{
Heavy Equipment Mechanic Dies when an Elevated Dump Truck Tag Axle Pins Him to the Concrete Floor
}

\author{
Incident Number: 13KY041
}

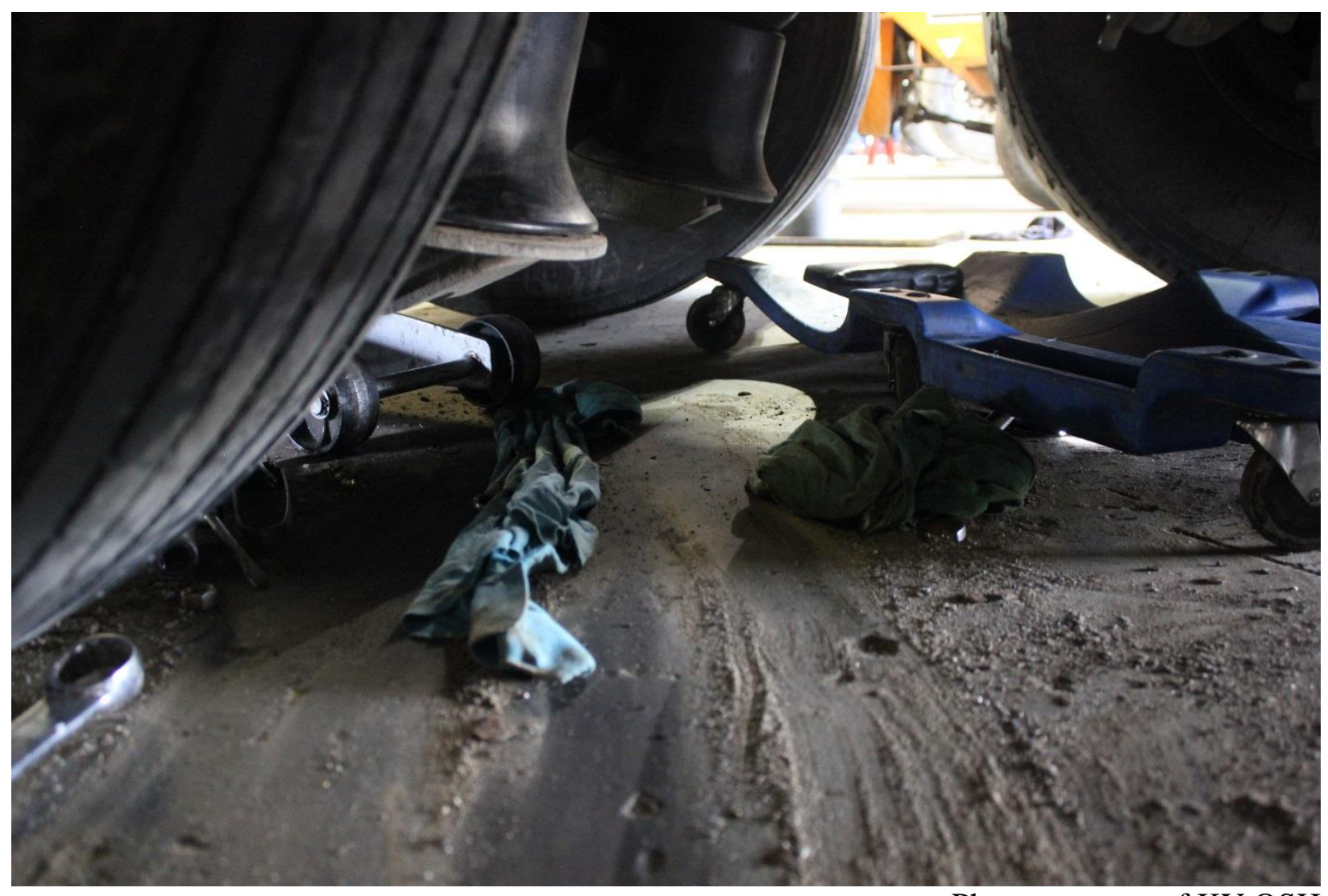

Photo courtesy of KY OSH

Kentucky Fatality Assessment and Control Evaluation Program Kentucky Injury Prevention and Research Center 333 Waller Avenue

Suite 242

Lexington, Kentucky 40504

Phone: 859-323-2981

Fax: 859-257-3909

www.kiprc.uky.edu

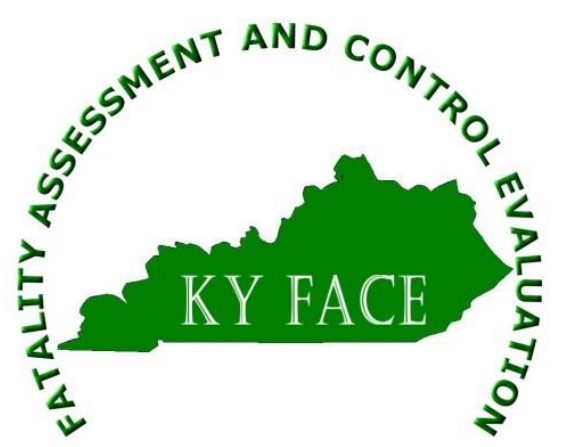




\section{Kentucky Fatality Assessment and Control Evaluation (FACE) Program Incident Number: 13KY041 \\ Release Date: April 7, 2015 \\ Subject: Mechanic Dies when an Elevated $1800 \mathrm{lb}$. Tag Axle Pins Him to the Concrete Floor.}

\section{$\underline{\text { Introduction }}$}

On September 19, 2013, at approximately 4:28 p.m. a 58-year-old heavy equipment mechanic was replacing an air bag on a tri-axle dump truck. The victim was under the truck and axle, which was resting on a hydraulic floor jack. While the victim was under the axle, he inadvertently placed his hand on the jack causing the floor jack to lower and pin him between the axle and the concrete floor. At 4:48 p.m. the shop security camera shows the victim's fellow mechanic return to the shop after he finished repairing a truck he was working on. He returned to the shop where the victim was working, to get ready to leave for the day. He yelled for the victim but received no answer. The mechanic observed the victim's legs and called out his name again, with no response. The mechanic walked around the truck to the passenger side and observed the victim's left hand on the handle of the jack. The mechanic removed the victim's hand from the jack and shook him without getting a response. He yelled for other employees to dial 911 for assistance. The victim's head was pointed toward the jack which was on the front side of the tag axle. The victim was lying on his right side with $1 / 3$ of his body on the creeper. The mechanic started jacking the jack but it would not move. He then turned the handle and the jack started elevating. Once the axle was lifted off the victim, another employee pulled the victim out from under the truck on the creeper. Employees trained in first aid and CPR started CPR and put an AED device on the victim and placed a call to EMS at 4:51pm. EMS and the Sheriff arrived six minutes after the call was placed, and the victim was transported via ambulance to the hospital. After being crushed by the dump truck, the victim succumbed to his injuries due to compression asphyxia on September 21, 2013 at 1:50 am.

To prevent future occurrences of similar incidents, the following recommendations have been made:

Recommendation No. 1: Employers shall ensure that employees using jacks must crib, block, or otherwise secure the loads immediately after they have been raised. ${ }^{1}$

Recommendation No. 2: Employers should conduct heavy equipment mechanic safety training on the correct procedures for air bag installation.

Recommendation No. 3: Employers shall conduct annual worker safety training for all employees exposed to hazards in the workplace. ${ }^{2}$ 


\section{$\underline{\text { Employer }}$}

The employer was a sand, gravel, clay, ceramic, refractory minerals, mining and quarry company with six divisions, employing 225 employees. The business was started in 1914 and celebrated its $100^{\text {th }}$ birthday this year.

\section{Written Safety Programs and Training}

The employer's new employee safety orientation consisted of four pages of safety rules; there was no other documented worker safety training. The use of the stands/cribbing was not included in the safety rules, and the victim was not instructed on the use of the jack stands/cribbing. The victim received instructions on slings/rigging, jack stands, ladders, man basket, etc., but not on the requirements for installation of air bags on a dump truck.

\section{$\underline{\text { Victim }}$}

The victim was a 58-year-old heavy equipment mechanic, married with two grown children and with over 40 years of experience in the industry. Despite the fact that the victim was a seasoned professional in his line of work, he had only been with this company for 9 days before the fatal incident.

\section{$\underline{\text { Incident Scene }}$}

The incident scene was a large equipment maintenance shop where general maintenance activities on equipment took place.

\section{Weather}

September 19, 2013 had scattered clouds with temperatures ranging from 76 to 86 degrees Fahrenheit.

\section{$\underline{\text { Equipment }}$}

The equipment was a Mack dump truck. The width of the outside tires on the truck was 92" each, and the width of that inside tires was 50" each. The height of the truck frame was 8.5-11inches above the concrete floor. The weight of the axle, wheels, tires, etc. was $1800 \mathrm{lbs}$.

\section{Investigation}

The Kentucky Fatality Assessment and Control Evaluation Program was notified by the Kentucky Labor Cabinet of an occupational fatality involving a heavy equipment mechanic.

On the afternoon of September 19, 2013, a dump truck was brought into the maintenance shop and was leaking air. After a head mechanic assessed the truck, it was determined that an air bag was blown on the left side of the tag axle. An air bag allows a truck driver to raise or lower the tag axle during transportation of loads on roadways, in order to balance the load on curves. The 
head mechanic spoke with the victim about performing the air bag job and the victim replied he had done many similar jobs. The head mechanic then walked outside to work on another vehicle for about 5 minutes. After the head mechanic repaired the other truck, he returned to the shop to get ready to leave for the day. He yelled for the victim but received no answer. The head mechanic observed the victim's legs and called out his name again, with no response. The head mechanic walked around the truck to the passenger side and observed the victim's left hand on the handle of the jack. The head mechanic removed the victim's hand from the jack and shook him without getting a response. He yelled for other employees to dial 911 for assistance. The victim's head was pointed toward the jack which was on the front side of the tag axle. The victim was lying on his right side with $1 / 3$ of his body on the creeper. The head mechanic started jacking the jack but it would not move. He then turned the handle and the jack started working. Once the axle was lifted off the victim, another employee pulled the victim out from under the truck on the creeper. Employees trained in first aid and CPR, started CPR and put an AED device on the victim. EMS and the Sheriff arrived at 4:57 p.m., and the victim was transported via ambulance to the hospital where he succumbed to his injuries on September 21, 2013 at 1:50 a.m.

The shop manager stated that in order to install an air bag, one end of the bag would be placed on the frame and then depending on which end of the bag was installed, the axle would be raised or lowered to connect the other end of the bag to the frame. It appeared the victim followed this procedure and had jacked the axle up, installed the top of the air bag to the frame and attempted to lower the axle to finish installing the air bag on the lower frame, when he was caught between the frame and the concrete floor.

\section{Cause of Death}

The cause of death was compression asphyxia, blunt trauma to ribs.

\section{$\underline{\text { Recommendations and Discussions }}$}

\section{Recommendation No. 1: Employers should ensure employees using jacks must crib, block or otherwise, secure the loads immediately after they have been raised. ${ }^{2}$}

All hydraulic jacks will leak off and it's important that you never get under any type of vehicle that is only being held up by hydraulics.

According to OSHA regulation, 29 CFR 1910.244 (a)(2)(iii) of the OSHA standards specifically states "after the load has been raised, it shall be cribbed, blocked, or otherwise secured at once". This fatality could have been avoided had the employer enforced this standard and trained all the mechanics accordingly. Had the victim cribbed the raised load immediately after raising it, the truck would have been secured by the cribbing when the victim inadvertently released the jack handle. 
Recommendation No. 2: Employers should conduct heavy equipment mechanic safety training on the correct procedures for air bag installation.

The victim had 30 years prior experience in mechanical work. There were no procedures or safety training for the employees on how to properly install air bags.

Recommendation No. 3: Employers shall conduct new and annual worker safety training for all employees exposed to hazards in the work place.

To ensure the safety of all employees, the employer shall conduct new and annual safety training for all employees that are exposed to hazards in the work place. This ensures that the employees are refreshed on what to do in all types of situations to keep them working safely. The victim was not trained on the use of the jack stands and or cribbing, when installing air bags on the truck. Employers should never make the assumption that an employee who has 30 years on the job with another employer knows how to work safely.

\section{$\underline{\text { Keywords }}$}

Floor jacks

Cribbing

Jack stands

Raised loads

\section{$\underline{\text { References }}$}

1"Hand and Portable Powered Tools and Other Hand-Held Equipment" 29 C.F.R. § 1910.244 (1984). Web. 15 October, 2014.

2 "Occupational Health and Safety Administration". Training Requirements in OSHA Standards and Training Guidelines. 1998. Web. 16 October, 2014.

\section{Acknowledgements}

The Kentucky FACE program would like to thank the Kentucky Labor Cabinet and KY OSH for their assistance with this report.

The Kentucky Fatality Assessment \& Control Evaluation Program (FACE) is funded by grant 2U60OH008483-10 from the Centers for Disease Control and Prevention and the National Institute for Occupational Safety and Health. The purpose of FACE is to aid in the research and prevention of occupational fatalities by evaluating events leading to, during, and after a work related fatality. Recommendations are made to help employers and employees have a safer work environment. For more information about FACE and KIPRC, please visit our website: www.kiprc.uky.edu 


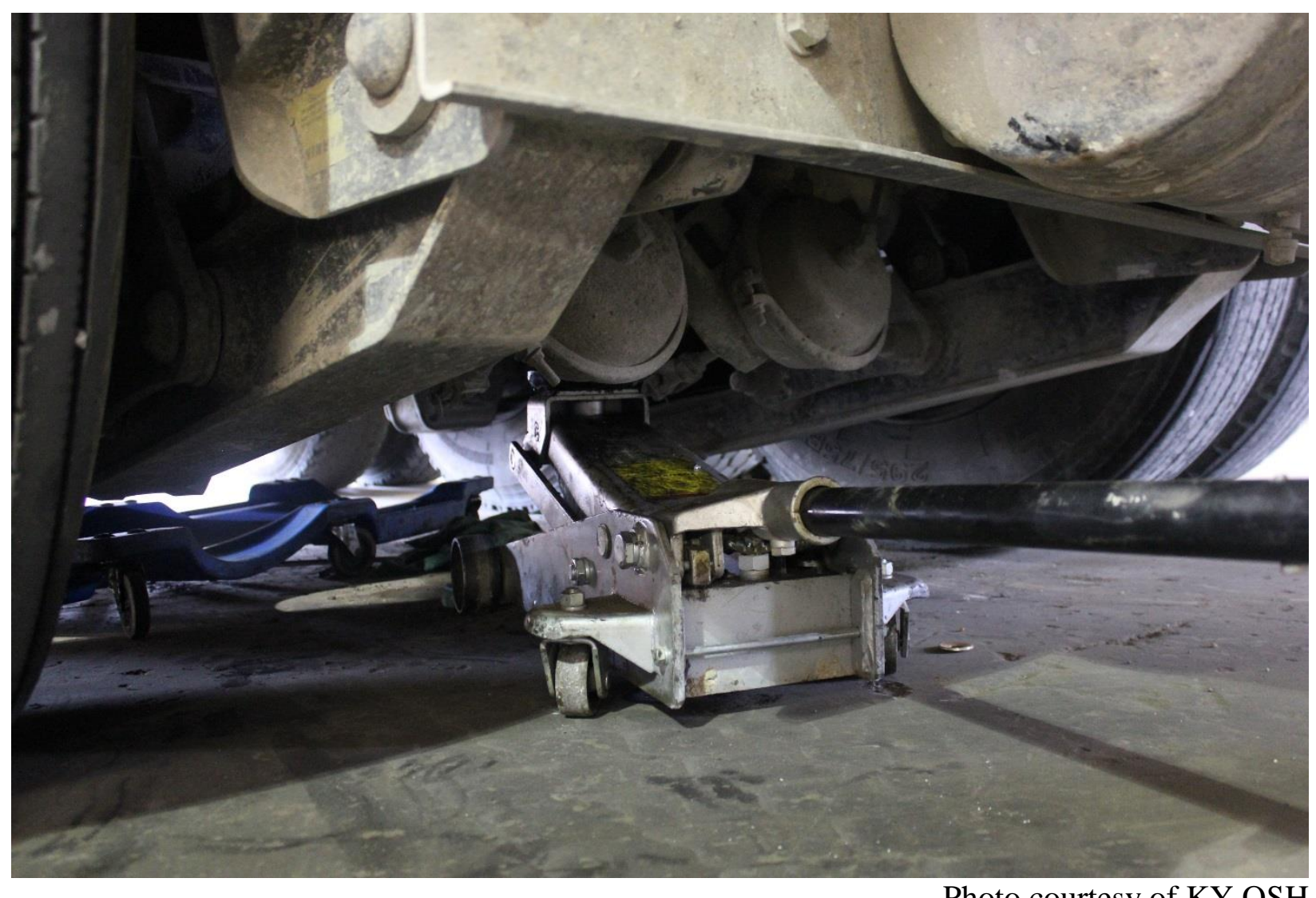

Photo courtesy of KY OSH 


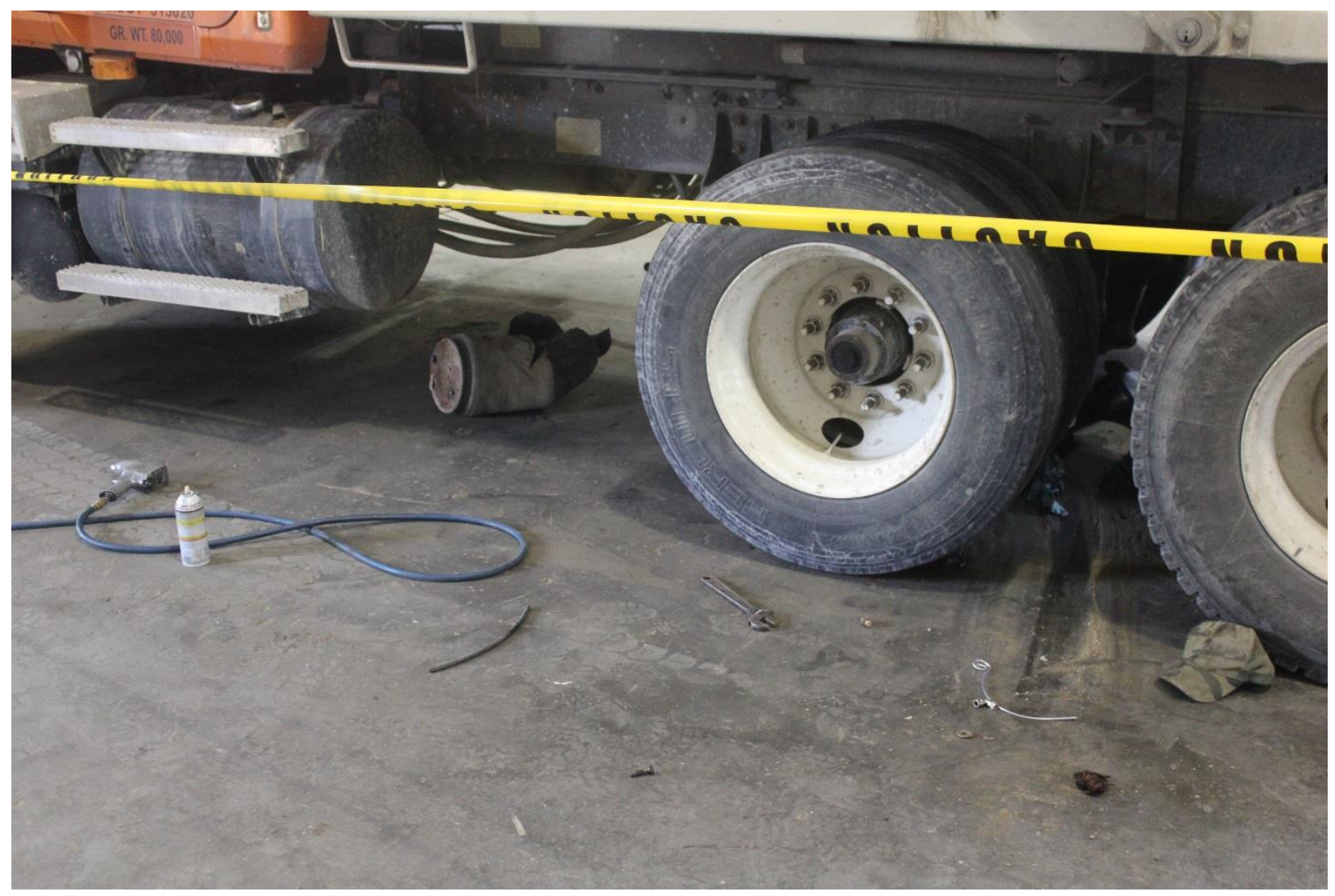

Photo courtesy of KY OSH 